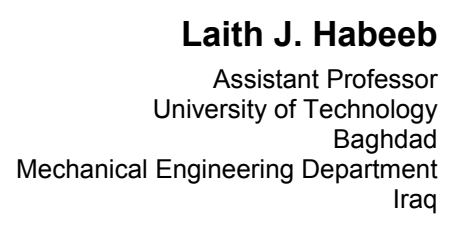

Fouad A. Saleh
Assistant Professor
University of Almustansiriya
Baghdad
Mechanical Engineering Department

Bassim M. Maajel

Assistant Lecturer University of Almustansiriya Baghdad

Mechanical Engineering Department

\section{CFD Modeling of Laminar Flow and Heat Transfer Utilizing Al2O3/Water Nanofluid in a Finned-Tube with Twisted Tape}

This study investigates numerically heat transfer augmentation using water-based $\mathrm{Al}_{2} \mathrm{O}_{3}$ nanofluid flowing in a circular cross-sectional tube under constant inlet temperature in laminar flow conditions. The Al2O3/water nanofluid with different volume fractions (3\% and 5\%) and twisted tape twist ratio of $(H / D=1.85)$ are employed, and Reynolds numbers of 678 to 2033 in a laminar flow are considered. The numerical analysis is used to solve the governing partial differential equations in three dimensions. Results of the flow structure, velocity vector, and temperature field are reported. The numerical results indicate that the heat transfer rate becomes more remarkable when employing nanofluid. The maximum 46\% enhancement is obtained in the convective heat transfer coefficient by using $\mathrm{Al}_{2} \mathrm{O}_{3}$ water nanofluid at $5 \%$ particle volume fraction and Reynolds number of 678, comparing with pure water. It is also found that heat transfer enhancement increases with an increase in the particle volume concentration and Reynolds number.

Keywords: Typical twisted tape, Nanofluid, Finned-Tube, Laminar Flow, CFD Modeling.

\section{INTRODUCTION}

In the past decades, many different techniques have been utilized in various energy providing devices to improve the poor thermal performance of conventional heat transfer fluids (water, engine oil, and ethylene glycol) which are widely used in many industrial cooling or heating applications. Currently, there are different ways existing for increasing heat transfer in heat exchangers, that can be divided into two groups: active and passive. An enhancement in heat transfer using a nanofluid is a method presented by Choi [1].

Nanofluid is a new class of heat transfer fluids. The use of nanofluids for heat transfer enhancement is one of the passive heat transfer techniques employed in many heat transfer applications. Solids have greater thermal conductivity than liquids. Thus, dispersing nano-particles, generally a metal or metal oxide, in fluids can greatly improve the thermal conductivity of liquids and, in turn, can help to improve their thermal characteristics. Using nanofluids has various practicable benefits such as improving of heat transfer rate, size reduction and miniaturization of heat transfer system as well as minimizing clogging. A large number of studies have conducted numerically to determine the convective heat transfer characteristics of nanofluids in laminar flow regimes.

Computational technology advancement has exten-

Received: September 2018, Accepted: October 2018

Correspondence to: Dr Laith Jaafer Habeeb

Mechanical Engineering Department, University of

Technology, P.O.Box (19006), Baghdad, Iraq

E-mail: laithhabeeb1974@gmail.com

doi: 10.5937/fmet1901089H

(C) Faculty of Mechanical Engineering, Belgrade. All rights reserved ded solution methods for the complicated mathematical equations by numerical analysis, especially CFD. In predicting both internal and external flows, the CFD solution variables place emphasis on predicting the true characteristics of flows in real interaction. CFD has been applied to analyze the heat transfer enhancement in several types of heat exchangers with twisted tapes inserts.

Heat transfer enhancement with flow of nanofluids in a tube has been observed; the use of twisted tape insert for further augmentation is the objective of this study. Number of researchers worked in this field, and they obtained results and conclusions that are discussed briefly below. Several investigators have investigated heat transfer enhancement in a circular finned-tube with nanofluid and tube inserts. In addition, there is an improvement in the finned-tube performance comparing with pure deionized (DI) water.

Pathipakka and Sivashanmugam [2] proposed a CFD simulation for laminar heat transfer characteristics using $\mathrm{Al}_{2} \mathrm{O}_{3}$ /water nanofluids in a uniform heat fluxed tube equipped with helical twist tape inserts. Twist tape of twist ratios 2.93, 3.91, and 4.89 with three different volume concentrations of $0.5 \%, 1 \%$, and $1.5 \% \mathrm{Al}_{2} \mathrm{O}_{3}$ /water simultaneously were used in the simulation. The maximum heat transfer enhancement of $31.29 \%$ was obtained with the use of helical insert of twist ratio 2.93 together with nanofluid with volume concentration of $1.5 \%$ at Reynolds number of 2039.

Paul et al. [3] investigated numerically heat transfer, friction and thermal performance characteristics of $\mathrm{CuO} /$ water nanofluid using Ansys Fluent 14.0. The nanofluid was employed in a circular tube equipped with modified twisted tape with alternate axis (TA). The 
concentration of nanofluid was varied from 0.3 to $0.7 \%$ by volume while the twisted ratio $(y / w)$ of TA was kept constant at 3 . The experiments were performed in laminar regime ( $R e$ No. spanned $830 \leq \operatorname{Re} \leq 1990)$. To evaluate heat transfer enhancement and the increase in the friction factor, the Nusselt number and friction factor of the base fluid in the plain tube were employed as reference data.

Mohamad et al. [4] reported a numerical study on heat transfer enhancement of $\mathrm{CuO} /$ water nanofluid in a constant heat fluxed tube fitted with classical and one side parabolic-cut twist tape inserts using Fluent version 6.3.26. Twisted tapes of different twist ratios $(\mathrm{y}=2.93$, 3.91 , and 4.89) and different cut depths ( $\mathrm{w}=0.5,1$, and $1.5 \mathrm{~cm}$ ) were simultaneously used with $2 \%$ and $4 \%$ volume concentration of $\mathrm{CuO}$ nanofluid for simulation. Their results elaborated that the parabolic cut twist tape of twist ratio $\mathrm{y}=2.93$ and cut depth $\mathrm{w}=0.5$ with $4 \%$ $\mathrm{CuO}$ nanofluid offers about $10 \%$ enhancement for the Nusselt number than that of classical twisted tape at the same conditions.

Salman et al. [5] studied numerically heat transfer of water in a uniformly heated circular tube fitted with Vcut twisted tape inserts in laminar flow using FLUENT version 6.3.26. Classical and elliptical cut twisted tape with twist ratio $(\mathrm{y}=2.93,3.91,4.89)$ and different cut depths $(\mathrm{w}=0.5,1,1.5 \mathrm{~cm})$ were employed for the simulation. The results showed that the V-cut twisted tape with twist ratio $(\mathrm{y}=2.93)$ and cut depth $(\mathrm{w}=$ $0.5 \mathrm{~cm}$ ) present a maximum heat transfer rate with significant increase in friction factor.

Kharat et al. [6] developed the new correlation of heat transfer coefficient for concentric helical coils of a heat exchanger depending on experimental work and CFD simulation. Fluent 6.3.26 was used to improve the heat transfer coefficient correlation for the flue gas side to optimize the gap between concentric coils.

Rao et al. [7] conducted a CFD simulation analysis for thermal-hydraulic characteristics of $\mathrm{CuO}+(30 \%$ propylene glycol (PG)+70\%water) at different concentrations $(0.025 \%$ and $0.1 \% \mathrm{CuO})$ of nanofluids flow inside a circular tube and with inserts. For the heat transfer in a circular tube fitted with twisted tape inserts, the parameters are the pitch to inlet diameter ratio $H / D=10$ and $H / D=5$. Laminar and turbulence flow Reynolds number conditions were explained in this thesis. ANSYS FLUENT 6.2.3 was used for estimating the heat transfer enhancement of nanofluids at different volume concentrations, and at constant heat flux boundary condition. The data obtained by simulation was matched with that in the literature for a plain tube with the discrepancy of less than $\pm 15 \%$ for Nusselt number and $\pm 10 \%$ for friction factor. The simulated results for the tube fitted with twisted inserts were agreed with the literature values $\pm 18 \%$ for Nusselt number and $\pm 15 \%$ for friction factor. From the simulation analysis, it was shown that the $0.1 \%$ volume concentration $\mathrm{CuO}$ Nanofluid has a heat transfer enhancement of $17.16 \%$ compared to base fluid at 2000 Reynolds number.

Paul et al. [8] numerically investigated heat transfer, friction and thermal performance characteristics of
$\mathrm{CuO} /$ water nanofluid using ANSYS FLUENT 14.0. The nanofluid was employed in a circular tube equipped with modified twisted tape with alternate axis (TA). The concentration of nanofluid was varied from 0.3 to $0.7 \%$ by volume, while the twisted ratio $(\mathrm{y} / \mathrm{W})$ of TA was kept constant at 3 . The experiments were performed in laminar regime (Reynolds number spanned $830 \leq \mathrm{Re} \leq$ 1990). The uses of nanofluid together with typical twisted tape (TT), TA alone and TT alone have been also examined. Their results elaborated that the use of nanofluid with the TA provides considerably higher Nusselt number and thermal performance than that of nanofluid with the TT for all Reynolds numbers examined. The TA offered higher heat transfer rate than that for the TT by around $89 \%$.

Naphon [9] used in his experimental study hot and chilled water in horizontal copper double tube heat exchanger fitted with aluminum twisted tape inside. He studied the effects of relevant parameters on heat transfer and pressure drop. It was concluded that the twisted tape insert has a significant effect on enhancing heat transfer rate, however, the pressure drop also increases. Correlations for heat transfer coefficient and friction factor based on the experimental data were presented.

Chandrasekar et al. [10] reported the heat transfer and friction factor characteristics of $\mathrm{Al}_{2} \mathrm{O}_{3} /$ water nanofluid in a circular pipe under laminar flow with wire coil inserts. It was found that Nusselt number increases by $12.24 \%$ at $\mathrm{Re}=2275$ using the nanofluid with concentration of $0.1 \%$ volume compared to that of the base fluid (distilled water). By the uses of two wirecoil inserts with pitch ratios of 2 and 3 together with the nanofluid, Nusselt numbers were found to further enhance by $21.5 \%$ and $15.9 \%$ respectively.

Sundar and Sharma [11] studied the turbulent heat transfer and friction factor of $\mathrm{Al}_{2} \mathrm{O}_{3}$ nanofluid in circular tube with twisted tape inserts. Their results revealed that when nanofluid $(0.5 \%$ volume) and twisted tape (twist ratio of 5) are used simultaneously, heat transfer coefficients at Reynolds numbers of 10,000 and 22,000 are higher than those of water in a plain tube by $33.51 \%$ and $42.17 \%$ respectively.

Guo et al. [12] studied the heat transfer in a tube enhanced with a center-cleared twisted tape in laminar region. It was observed that the friction factor decreases with an increment of the central clearance ratio $(c)$ as it makes less baffled area at larger central clearance ratio.

Lin and Wang [13] investigated numerically the heat transfer in a round tube tailored with inserted tape. The conduction influence on the $(\mathrm{Nu})$, the heat transfer improvement sensitivity to the circumstances of thermal boundary using secondary flow, and its influence on the hydraulic boundary layer have been argued. The study data exposed that under fully developed flow, diverse tube surface thermal boundaries lead to diverse influences of conduction in the tape on features of heat transfer.

Yadav [14] investigated experimentally the drop of pressure features and heat transfer in a U-bend double pipe heat exchanger using a half-length twisted tape. Their results were compared with that of smooth tube. The data exposed that increasing the rate of heat transfer 
of the inserted tape found to be highly affected by vortex motion. The coefficient of heat transfer was observed to rise by $40 \%$ with half-length inserted tape insets in comparison with smooth tube. The performance of heat transfer of using half-length inserted tape was higher than that for smooth tube.

Sudarmadji et al., Sudarmadji, and Madhu [15-17] investigated the convective heat transfer and pressure drop of nanofluid in laminar flow regimes in circular pipes and conventional solar still at different temperatures and $\mathrm{Al}_{2} \mathrm{O}_{3}, \mathrm{CuO}$ and $\mathrm{TiO} 2$ volume concentrations in both cooling and heating processes. Experiment results showed that the convection heat transfer increases remarkably with the increase of the nanoparticles concentration under various values of Reynolds number. The pressure drop of nanofluid was found to increase slightly with increasing volume concentration. However, comparing with using pure water, the difference of the pressure drop was insignificant, so that the use of nanofluid has a little penalty on pressure drop. There was a greater possibility of negative efficiency during the start of the experiment while the ambient temperature was lower than water temperature $(\mathrm{Ta}>\mathrm{Tw})$. The daily exergy efficiency increases by $20 \%$ with increase in concentration of nano-particles in fluid $\left(\mathrm{Al}_{2} \mathrm{O}_{3}\right)$.

In the present work, a numerical investigation of heat transfer enhancement in a circular finned-tube induced by Classical configuration of vortex generator (Typical twisted tape) with $3 \%$ and $5 \%$ volume fractions of $\mathrm{Al}_{2} \mathrm{O}_{3}$ nanofluid is reported using CFD simulation. The main objective of the present work is to predict the flow structure (path line and velocity vector) and heat transfer (fluid temperature along the tube and in each cross section) behaviors in a tube with twisted tape (TT). The results obtained using this configuration was found to offer about $44 \%$ enhancement of the Nusselt number with significant increase in the friction factor than those of distilled water.

\section{TECHNICAL DETAILS}

\subsection{Physical Models}

The configurations of the finned-tube and typical twisted tape (TT) insert are shown in figures 1 and 2 , respectively. Copper tape of $1 \mathrm{~mm}$ thickness and $22 \mathrm{~mm}$ width is uniformly winding over a length $1500 \mathrm{~mm}$ to produce twist ratio of 1.85 . The twist ratio "TR" is defined as the ratio of the length of one full twist $\left(360^{\circ}\right)$ to the tape width. Aluminum finned-tube with a diameter (D) of $22 \mathrm{~mm}$ and length (L) of $1500 \mathrm{~mm}$ is used as a test section. Water which is assumed to be incompressible fluid with $\mathrm{Al}_{2} \mathrm{O}_{3}$ nanoparticles $(\mathrm{dp}=20$ $\mathrm{nm})$ are selected as the working fluid.

The thermophysical properties of fluid and materials used for simulation are shown in tables 1 and 2. Parameters like the Reynolds number (Re), Nusselt number $(\mathrm{Nu})$, friction factor (f) and thermal performance factor (f) are defined as follows:

$$
\operatorname{Re}_{\mathrm{nf}}=\frac{\rho_{\mathrm{nf}} \mathrm{w} \mathrm{D}_{\mathrm{i}}}{\mu_{\mathrm{nf}}}
$$

$$
\begin{gathered}
\mathrm{Nu}(\mathrm{z})=\frac{\mathrm{h}(\mathrm{z}) \mathrm{D}}{\mathrm{k}_{\mathrm{nf}}} . \\
\mathrm{f}=\frac{\Delta \mathrm{P}}{(\mathrm{L} / \mathrm{D})\left(\rho \mathrm{V}^{2} / 2\right)} . \\
\eta=\frac{\overline{\mathrm{Nu}}_{\text {nano }} / \overline{\mathrm{Nu}}_{\text {water }}}{\left(\mathrm{f}_{\text {nano }} / \mathrm{f}_{\text {water }}\right)^{1 / 3}} .
\end{gathered}
$$

The Reynolds numbers which is determined for the inner diameter in the inlet of the pipe before the twisted tape for velocity component in the z-direction referring to the inlet values, are set at $678,1009,1000,1353$, 1695 and 2033 in the computations. Heat transfer enhancement index or thermal performance factor is one of the key parameters necessary to define the heat transfer augmentation performance.

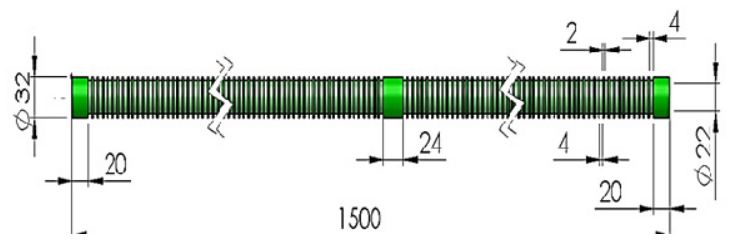

Figure 1. Physical geometry of finned tube

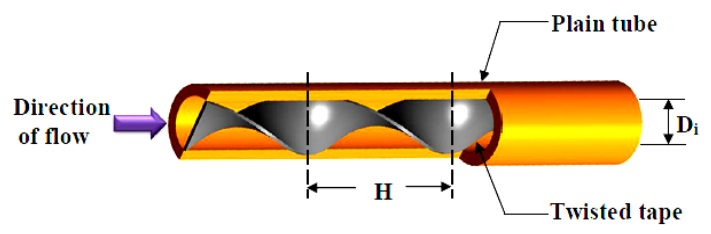

Figure 2. Diagram of a twisted tape insert inside a tube

Table 1. Properties of nanofluid with different concentration of $\mathrm{Al}_{2} \mathrm{O}_{3}$

\begin{tabular}{|c|c|c|c|}
\hline properties & $\phi=0 \%$ & $\phi=3 \%$ & $\phi=5 \%$ \\
\hline$k_{n f}(\mathrm{~W} / \mathrm{m} . \mathrm{K})$ & 0.600 & 0.631 & 0.652 \\
\hline$\rho_{n f}\left(\mathrm{~kg} / \mathrm{m}^{3}\right)$ & 998.2 & 1084.65 & 1142.29 \\
\hline$\mu_{n f}(\mathrm{Kg} / \mathrm{m} . \mathrm{s})$ & 0.001002 & 0.001332 & 0.001676 \\
\hline $\mathrm{C}_{p, n f}(\mathrm{~J} / \mathrm{kg} \mathrm{K})$ & 4182 & 3816.16 & 3603.03 \\
\hline$k_{n f} / k_{b f}$ & 1 & 1.051 & 1.086 \\
\hline$\mu_{n f} / \mu_{b f}$ & 1 & 1.329 & 1.672 \\
\hline
\end{tabular}

Table 2. The properties for the nanosized particle at $\left(25^{\circ} \mathrm{C}\right)$

\begin{tabular}{|c|c|c|c|c|}
\hline Particle & $\begin{array}{c}\text { Mean } \\
\text { diameter } \\
(\mathrm{nm})\end{array}$ & $\begin{array}{c}\text { Density } \\
\left(\mathrm{kg} / \mathrm{m}^{3}\right)\end{array}$ & $\begin{array}{c}\text { Thermal } \\
\text { conductivity } \\
\left(\mathrm{W} / \mathrm{m} .{ }^{\circ} \mathrm{C}\right)\end{array}$ & $\begin{array}{c}\text { Specific } \\
\text { heat } \\
\left(\mathrm{J} / \mathrm{kg} .{ }^{\circ} \mathrm{C}\right)\end{array}$ \\
\hline $\mathrm{Al}_{2} \mathrm{O}_{3}$ & 20 & 3970 & 40 & 765 \\
\hline
\end{tabular}

\subsection{Thermophysical Properties of Nanofluid}

The physical and thermal properties such as density and specific heat of the nanofluid are calculated using different formulae presented in the literature and outlined below in equations (5) to (8). All properties are calculated using bulk temperatures between inlet and outlet. 


$$
\begin{gathered}
\rho_{\mathrm{nf}}=\left(\frac{\mathrm{m}}{\mathrm{V}}\right)_{\mathrm{nf}}=\frac{\rho_{\mathrm{bf}} \mathrm{V}_{\mathrm{bf}}+\rho_{\mathrm{p}} \mathrm{V}_{\mathrm{p}}}{\mathrm{V}_{\mathrm{bf}}+\mathrm{V}_{\mathrm{p}}}=(1-\varphi) \rho_{\mathrm{bf}}+\varphi \rho_{\mathrm{p}} . \\
\mathrm{Cp}_{\mathrm{nf}}=\frac{(1-\varphi) \rho_{\mathrm{bf}} \mathrm{Cp}_{\mathrm{bf}}+\varphi \rho_{\mathrm{p}} \mathrm{C} \mathrm{p}_{\mathrm{p}}}{\rho_{\mathrm{nf}}} \cdot \\
\mu_{\mathrm{nf}}=\left(1+7.3 \varphi+123 \varphi^{2}\right) \mu_{\mathrm{bf}} \quad \cdot[18] \\
\mathrm{k}_{\mathrm{nf}}=\mathrm{k}_{\mathrm{bf}}(1+7.74 \varphi) \cdot[19]
\end{gathered}
$$

where $\varphi$ is the volume concentration and $\mu$ is the dynamic viscosity. The index nf, bf and $\mathrm{p}$ refer to nanofluid, base fluid and particle properties, respec-tively. In fact, there is no reliable database for viscosity and thermal conductivity of nanofluids and their values can vary significantly depending on the relation used to calculate them.

\section{NUMERICAL PROCEDURE}

\subsection{Geometry Creation with Meshing}

\subsubsection{Annular-Finned Tube}

A circular finned tube of diameter $22 \mathrm{~mm}$ and length 1500 $\mathrm{mm}$ is used as geometry. This 3-D geometry is created using Ansys Workbench and schematic view is shown in the figure (3). Unstructured meshing method is used for meshing the geometry. The mesh contains 67,096 nodes and 207,058 elements, as shown in figure (4).

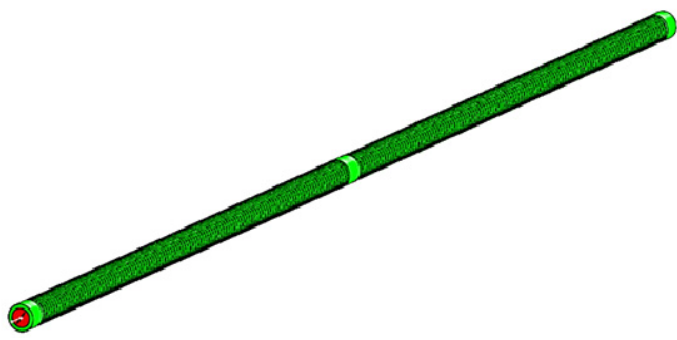

Figure 3. Diagram of a twisted tape insert inside a tube

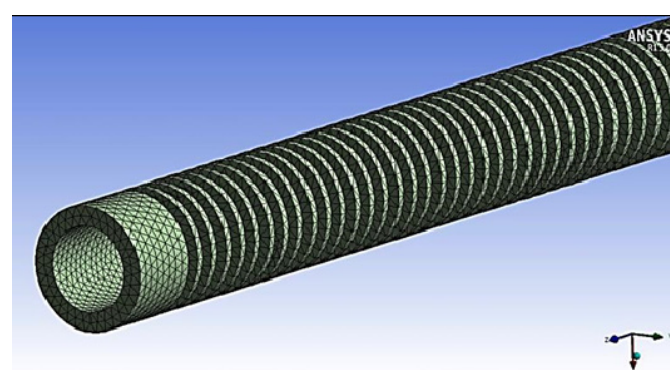

Figure 4. Diagram of a twisted tape insert inside a tube

\subsubsection{Twisted Tape Inserts inside a Finned Tube}

The schematic view of 3D geometry of twisted tape inserted inside the finned tube created by using Ansys code 15.0 software is shown in figure (5).

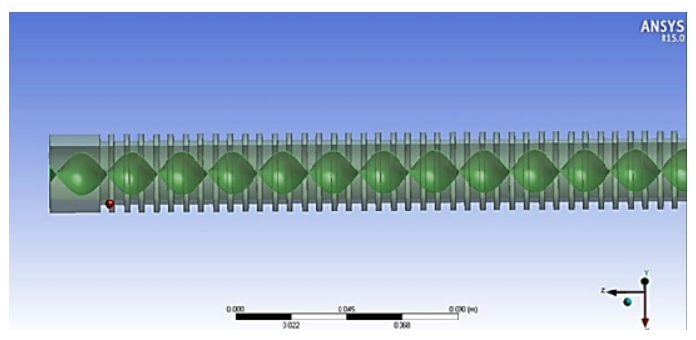

Figure 5. Diagram of a twisted tape insert inside a tube
The geometry is meshed into smaller cells. The meshing method used is patch independent tetrahedron. The geometry mesh contains 94,892 nodes and 44,044 elements as shown in figure (6).

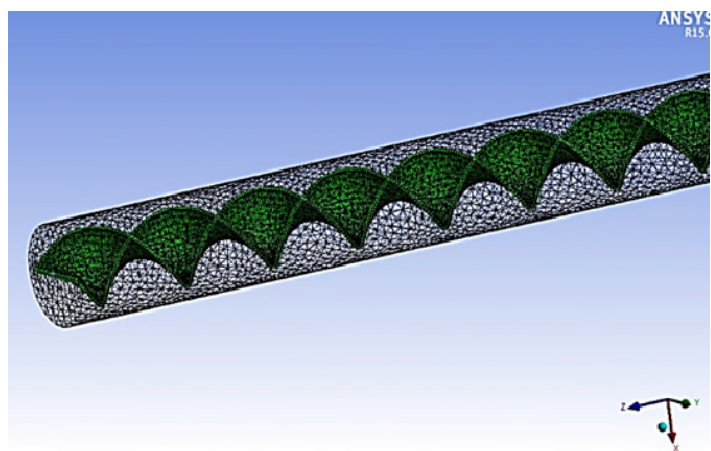

Figure 6. Diagram of a twisted tape insert inside a tube

\subsection{Mathematical Mode}

The mathematical equations used to describe the fluid flow are the continuity and momentum equations, which describe the conservation of mass and momentum, respectively. The momentum equations are also known as the Navier-Stokes equations. For flows involving heat transfer, another set of equations is required to describe the energy conservation. The continuity equation is derived by applying the principle of mass conservation to a small differential volume of the fluid. In Cartesian coordinates, the three equations of the following form are obtained.

\subsubsection{Continuity Equation (Conservation of Mass)}

$$
\frac{\partial u}{\partial x}+\frac{\partial v}{\partial y}+\frac{\partial w}{\partial z}=0
$$

\subsubsection{Momentum Equation}

The momentum equations are derived by applying Newton's second law of motion for differential volume of fluid. According to Newton's second law, the rate of change of momentum over a differential volume of fluid is equal to the sum of all external forces acting on this volume of fluid. The resulting momentum equations in Cartesian coordinates take the general form:

X-Momentum Equation:

$$
\rho_{n f}\left(u \frac{\partial u}{\partial x}+v \frac{\partial u}{\partial y}+w \frac{\partial u}{\partial z}\right)=-\frac{\partial p}{\partial y}+\mu_{n f}\left(\frac{\partial 2 u}{\partial x^{2}}+\frac{\partial 2 u}{\partial y^{2}}+\frac{\partial 2 u}{\partial z}\right) .
$$

Y-Momentum Equation:

$$
\rho_{n f}\left(u \frac{\partial v}{\partial x}+v \frac{\partial v}{\partial y}+w \frac{\partial v}{\partial z}\right)=-\frac{\partial p}{\partial y}+\mu_{n f}\left(\frac{\partial^{2} v}{\partial x^{2}}+\frac{\partial^{2} v}{\partial y^{2}}+\frac{\partial^{2} v}{\partial z^{2}}\right)
$$

Z-Momentum Equation:

$\rho_{n f}\left(u \frac{\partial w}{\partial x}+v \frac{\partial w}{\partial y}+w \frac{\partial w}{\partial z}\right)=-\frac{\partial p}{\partial z}+\mu_{n f}\left(\frac{\partial^{2} w}{\partial x^{2}}+\frac{\partial^{2} w}{\partial y^{2}}+\frac{\partial^{2} w}{\partial z^{2}}\right)$

\subsubsection{Energy Equation}

The Energy equation is derived from the first law of thermodynamics, which states that the rate change of 
fluid particle energy is equal to the rate of heat addition to the fluid particle plus the rate of work done on the particle. If we consider that the flow is incompressible, and the thermal conductivity value remains constant, the equation converts to the following shape:

$$
\left(\rho C_{p}\right)_{n f}\left(u \frac{\partial T_{n f}}{\partial x}+v \frac{\partial T_{n f}}{\partial y}+w \frac{\partial T_{n f}}{\partial z}\right)=K_{n f}\left(\frac{\partial^{2} T_{n f}}{\partial x^{2}}+\frac{\partial^{2} T_{n f}}{\partial y^{2}}+\frac{\partial^{2} T_{n f}}{\partial z^{2}}\right)
$$

\subsection{Boundary Conditions}

At the inlet, the fully developed profiles of velocity and temperature are specified. At the outlet, a pressureoutlet condition is used. A constant inlet temperature $(60 \mathrm{oC})$ is imposed on the tube inlet. On the surfaces of the tube wall and twisted tape, no slip conditions are applied. The single-phase approach for nanofluids is adopted in this numerical study. The base fluid and nanoparticles are assumed to perfectly mix and thus, can be treated as a homogeneous mixture. The flow is laminar and steady state. Moreover, the fluid phase and solid particles are assumed to be in thermal equilibrium and move with the same local velocity.

\subsection{Numerical Method}

In the present study, the governing differential equations (9) to (13) are solved numerically by incorporating FLUENT, ANSYS 15.0 package using finite control volume approach based on SIMPLE technique. In addition, the second order upwind scheme is used to solve the momentum and energy equations. Moreover, the geometries of the computational domains and the generated mesh are made with Ansys Workbench. A grid independency of the solution was done for the complex case study to ensure that the obtained results are not dependent to the adopted grid density.

For this purpose, three grid systems with about 2000000, 2500000 and 3000000 cells were adopted for a specific case with Reynolds number of 2033 and the tape twist ratio of 1.85 . The average Nusselt number for the base case is shown in figure (7). The variation trend in this figure implies that the grid system with 2000000 cells can be a good grid system for this problem, since there is no more noticeable improvement in the results with respect to grid number and calculation time enhancement. The under-relaxation factors considered were 0.3 and 0.7 for pressure and momentum, respectively. In addition, for all simulations the convergence criteria were of 10-3 for continuity and velocity components and 10-6 for energy. To have exact numerical simulation, which covers the problem features, good quality mesh generation is necessary. Because of twisting geometry of the problem, tetrahedral elements are used for meshing the whole domain. This is because it has the priority in the sophisticated geometries, as shown in figure (8). In addition, fine meshes are needed for near wall regions, grid independency of the problem defined required mesh size to have acceptable results. For all simulations performed in the present study, converged solutions are considered when the residuals resulting from the iterative process for all governing equations do not change with the iteration progress and the computational error may be ignored, then the iteration manually stopped. For most of the cases, the iterations are around (850-1000).

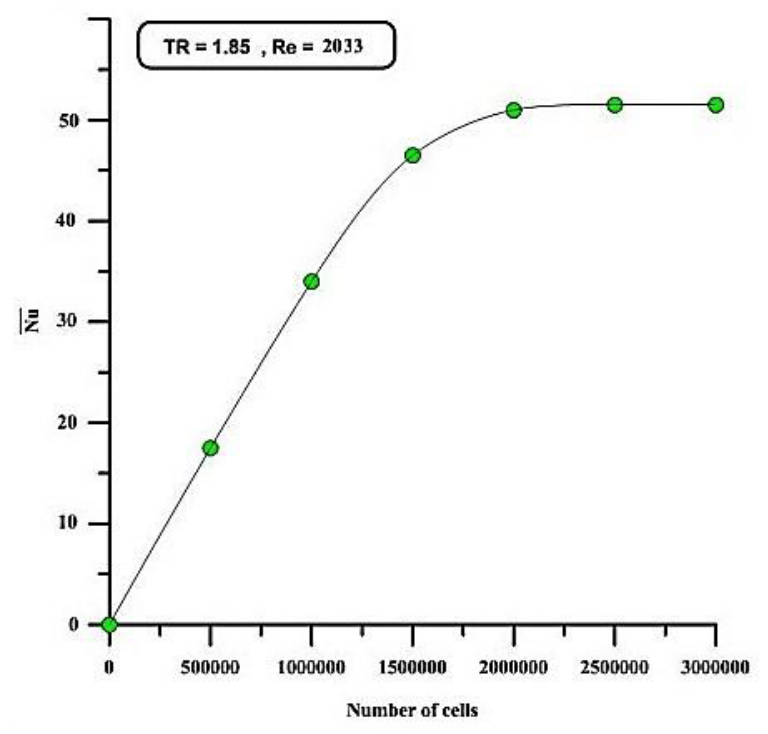

Figure 7. Diagram of a twisted tape insert inside a tube

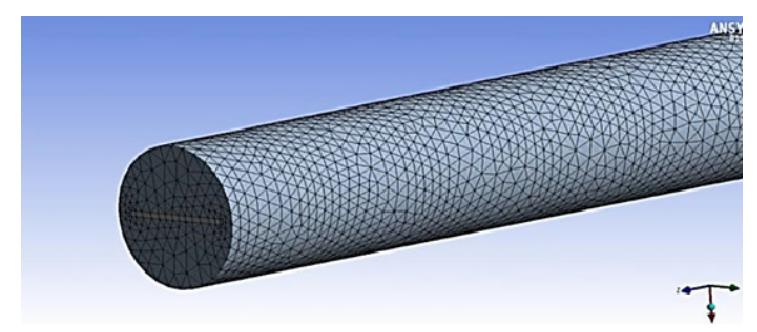

Figure 8. Diagram of a twisted tape insert inside a tube

\section{NUMERICAL PROCEDURE}

\subsection{Results Validation}

To verify the reliability and exactness of the numerical model, the simulated average Nusselt numbers across the tube versus $(\mathrm{Re})$ are compared with those obtained from another experimental data [20], as shown in figure (9). The experimental and simulated Nusselt number as well as the percentage of errors for five randomly selected data of flow rate Q in liter per hour (LPH) for $\varphi$ $=5 \%$ are given in the table (3). In addition, the simulated friction factors along the tube versus (Re) are compared with those obtained from experiments and shown in figure (10). From these figures, it is observed that the simulated values are matching with the experimental values within $\pm 11 \%$ error for average Nusselt number and $\pm 9 \%$ error for friction factor respectively.

Table 3. Experimental and simulated $(\overline{N u})$ comparison for laminar flow (water)

\begin{tabular}{|c|c|c|c|}
\hline Q (LPH) & EXP. & NUM. & e \% \\
\hline 20 & 18.315 & 17.334 & 5.35 \\
\hline 30 & 26.305 & 23.298 & 11.43 \\
\hline 40 & 30.928 & 27.994 & 9.48 \\
\hline 50 & 35.576 & 31.823 & 10.54 \\
\hline 60 & 41.813 & 38.404 & 8.15 \\
\hline
\end{tabular}




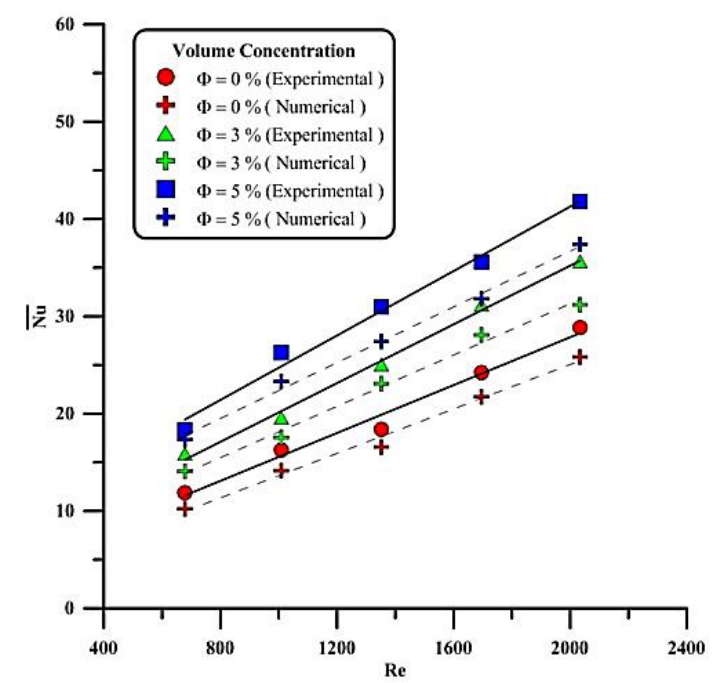

Figure 9. Numerical versus experimental results of ( ) for laminar flow

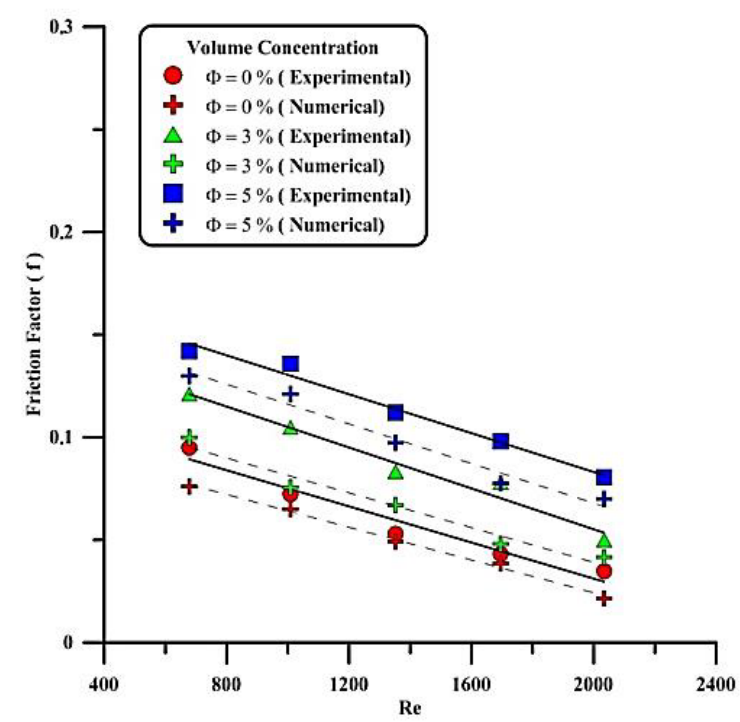

Figure 10. Numerical versus experimental results of $(f)$ for laminar flow

\subsection{Heat transfer results}

In this study, the numerical results obtained from using finite volume method single-phase model using the commercial CFD program Ansys-Workbench 15.0, package are presented to show both the flow and heat transfer characteristics in form of path lines, velocity vectors, and contours for the present models.

\subsubsection{Thermal Effect of Twisted Tape and Nanofluid}

The simulated data are converted into local values of heat transfer coefficient, which in turn converted into local values of Nusselt number along the tube, as shown in figure (11). From this figure, it is noticed that the values of $\mathrm{Nu}$ are high at the thermal entrance region and then become less when the flow advances towards the end of the tube due to the increasing effect of boundary layer. The presence of twisted tape causes an increase in the values of Nusselt number because of the interruption in the fluid flow and decreasing the thermal boundary layer thickness caused by the twisted tape.

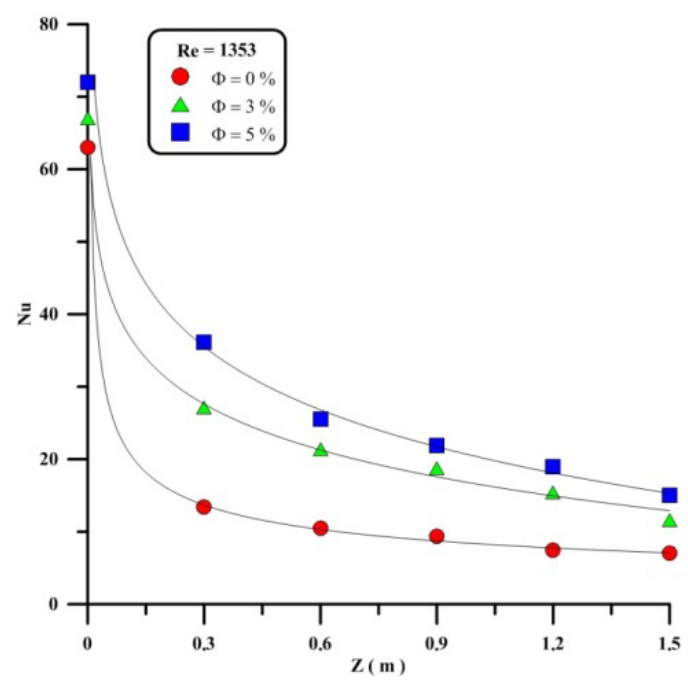

Figure 11. The variation of local $(\mathrm{Nu})$ along the tube for laminar flow

The variation in average Nusselt number with Reynolds number for the finned tube with typical twisted tape is demonstrated in figure (12). In general, it is shown that the average Nusselt number increases as the Reynolds number increases for all the ranges of Reynolds number.

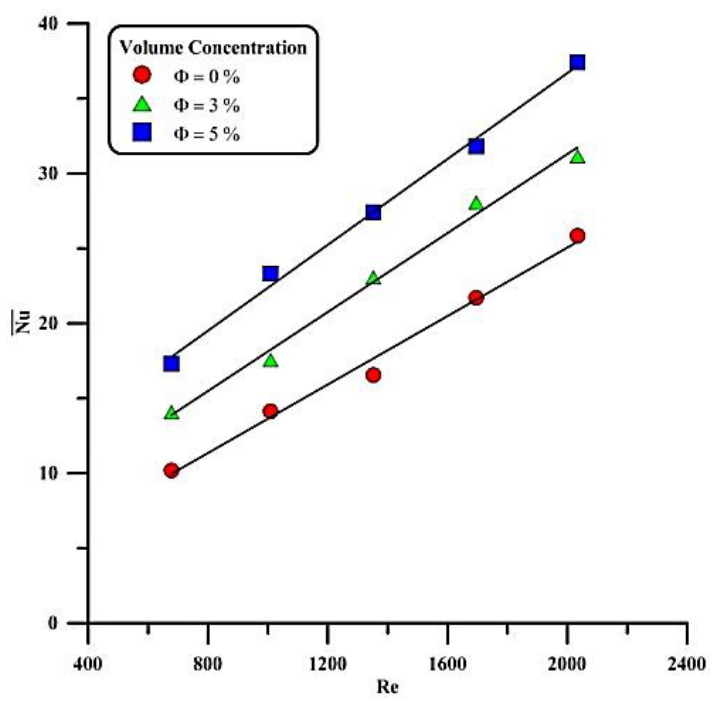

Figure 12. The effect of $(\mathrm{Re})$ and $(\varphi)$ on ( ) for laminar flow

For nanofluid, as the concentration increases, the ( $\overline{\mathrm{Nu}}$ ) increases because the effective thermal conductivity of nanofluid increases with increasing the volume fraction of the nanoparticles, which is explained by Brownian motion of the nanoparticles and molecular level layering of the liquid at the liquid - particle interface (wettability). Enhanced thermal conductivity is found to reduce the resistance to thermal diffusion in the laminar sub-layer of the boundary layer.

\subsubsection{Hydrodynamic Effect of Twisted Tape and Nanofluid}

The pressure drop for typical twisted tape in hydrodynamic flow through a circular-finned tube is calculated numerically to investigate the flow characteristics for the tube with twisted tape for the twist ratio $(\mathrm{TR}=1.85)$. Figure 
(13) illustrates the variation of friction factor with Reynolds number. From the simulated results, it can be noted that the friction factor tends to decrease with an increase in Reynolds number. Generally, the friction factor decreases as the Reynolds number increases for the whole range of Reynolds number.

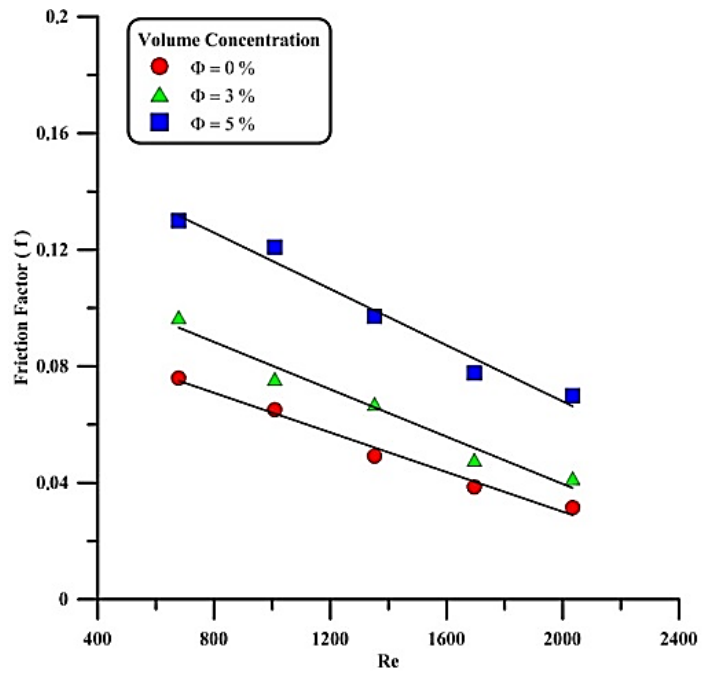

Figure 13. The effect of $(R e)$ on friction factor for laminar flow

For all cases with nanofluid and at the same Reynolds number, the friction factor increases with increasing the volume concentration value, due to increasing viscosity of the working fluid that leads to increase the shear force on the tube wall acted by larger numbers of nanoparticles, leading to an increase of the friction factor.

\subsection{Velocity Vectors in the Tube}

Figure (14) shows 3-D streamlines of the flow in a tube fitted with the typical twisted tape. It is clear that the particles move longer path than that for plain tube, and this helical movement provides a force to break the sublayer near the wall.

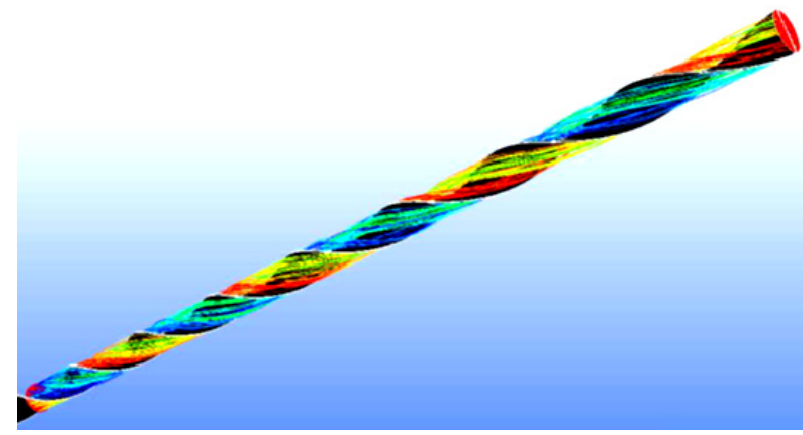

(A)

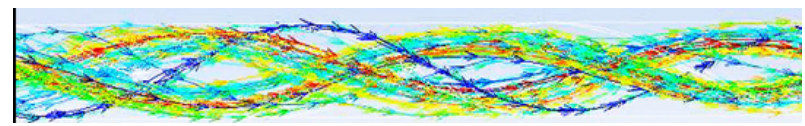

(B)

Figure 14. Path lines of the flow in a tube fitted with typical twisted tape

Figure (15) shows the velocity vectors at different sections along the tube for $(\varphi=5 \%)$ with $(\operatorname{Re}=2033)$.
At section $(Z=0 \mathrm{~m})$, the sudden impact of the flow with the twisted tape is shown, and then a secondary flow is induced and a rotational movement is noticed along the tube, which enhances the heat transfer in the tube.
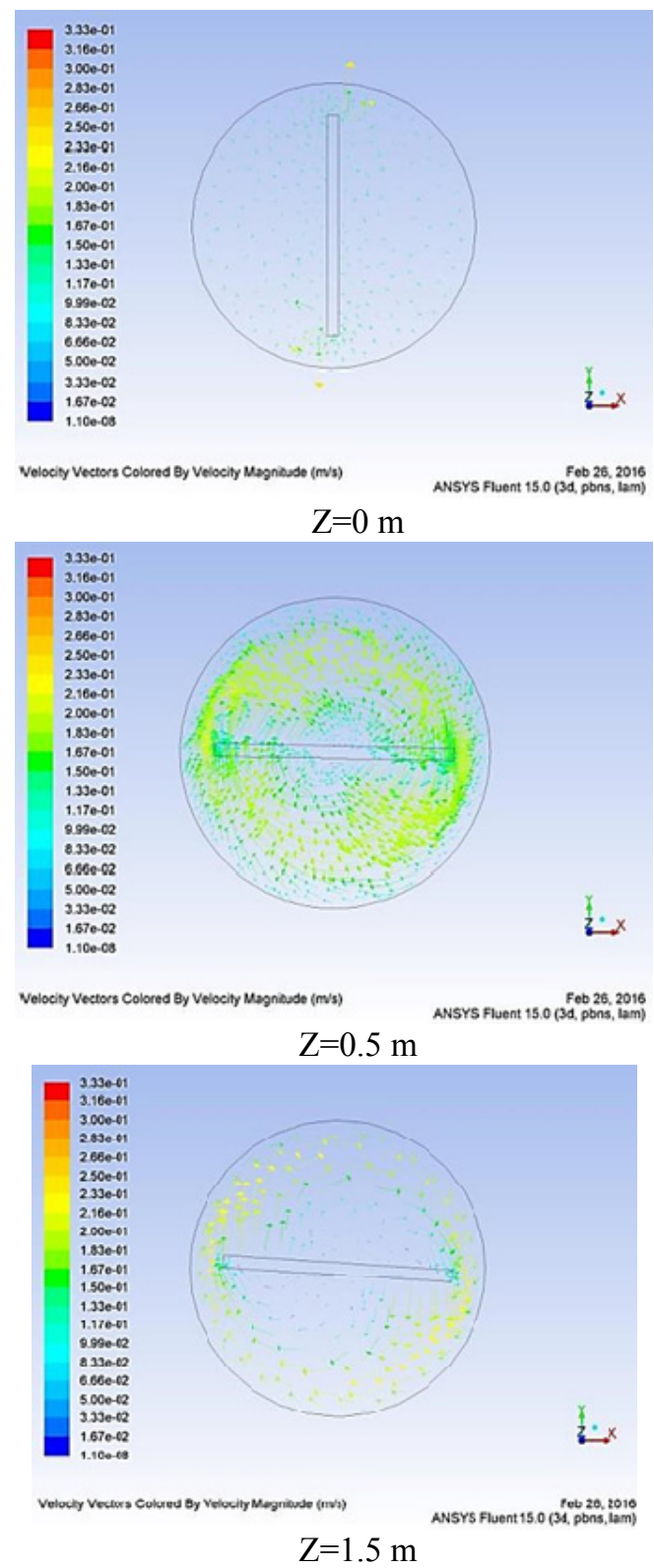

Figure 15. Velocity vectors in $(\mathrm{m} / \mathrm{s})$ at $(\mathrm{Re}=\mathbf{2 0 3 3})$ for nanofluid $(\varphi=5 \%)$

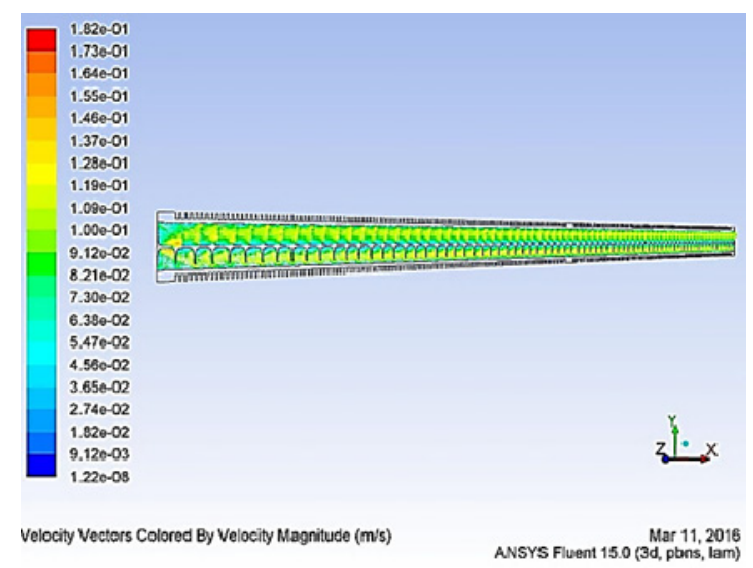

Figure 16 . Velocity vectors in $(\mathrm{m} / \mathrm{s})$ along the test section for nanofluid $(\varphi=3 \%)$ and $(\operatorname{Re}=1353)$ 
Figure (16) shows a 3-D view of longitudinal section (mid plane) for velocity vector at volume concentration $(3 \%)$ with $(\mathrm{Re}=1353)$. From this figure, it can be noted that the velocity distribution at $\mathrm{Z}=0 \mathrm{~m}$ is uniform. In addition, the fluid velocity at the center of the tube increases and then gradually decreases near the tube and tape walls.

\subsection{Temperature and Velocity Contours}

Figure (17) depicts a 3-D view of static temperature distribution along the test section at the mid-plane (tube and environment) for nanofluid of volume concentration $(3 \%)$ and $(\operatorname{Re}=1009)$.

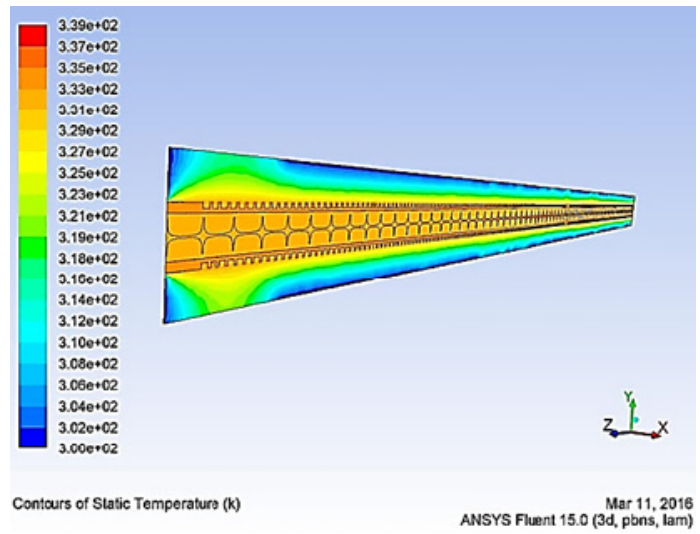

Figure 17. Temperature distribution along the test section for $(\varphi=3 \%)$

Figure (18) presents static temperature contours at the inlet and the outlet for distilled water at $\mathrm{Re}=1009$ toward $\mathrm{Z}$ direction. At the end of the pipe, there are two identical cold contours because of the twisted tape, which deform the two helical paths.
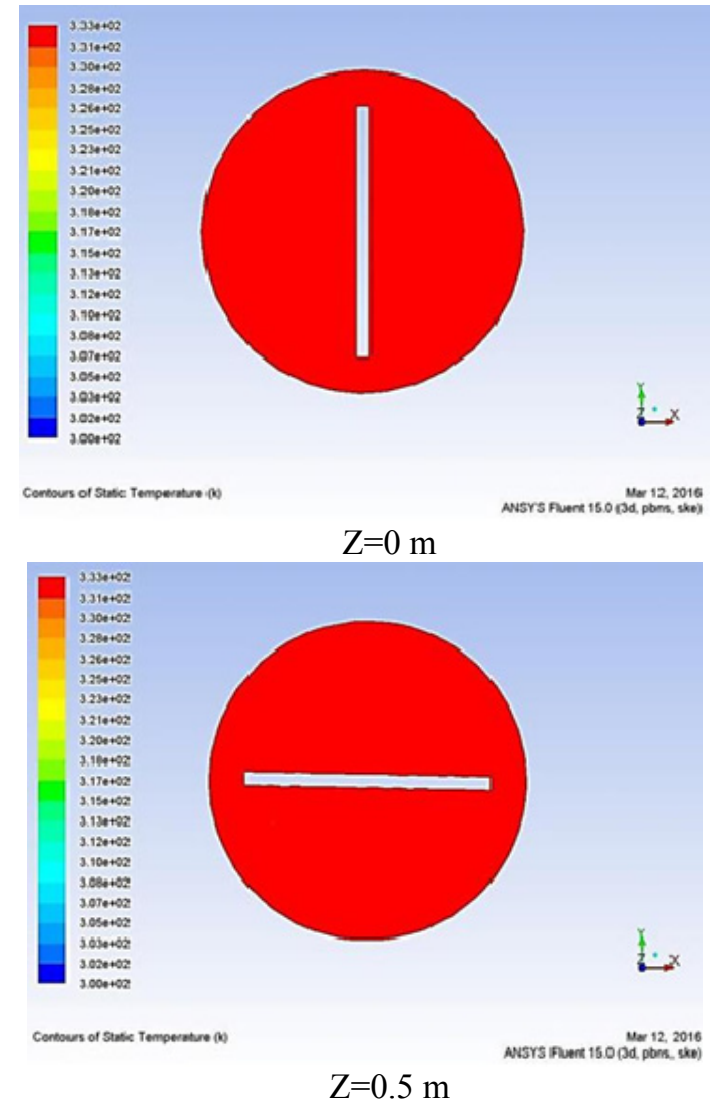

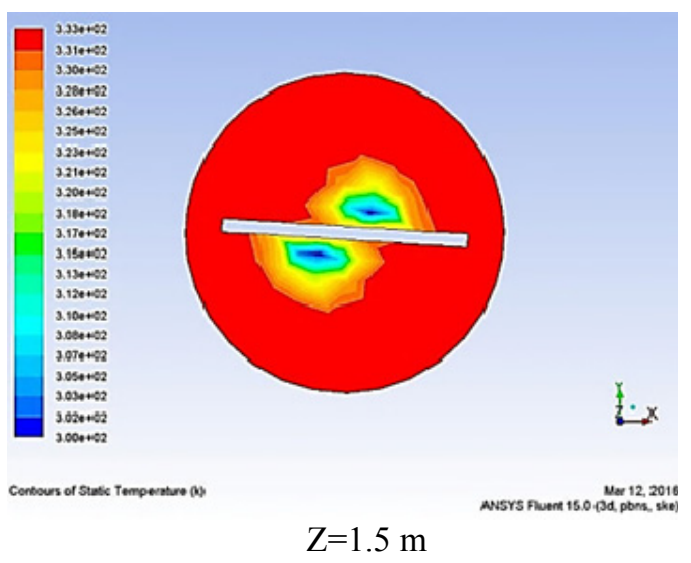

Figure 18. Temperature contours for distilled water at $(\operatorname{Re}=1009)$
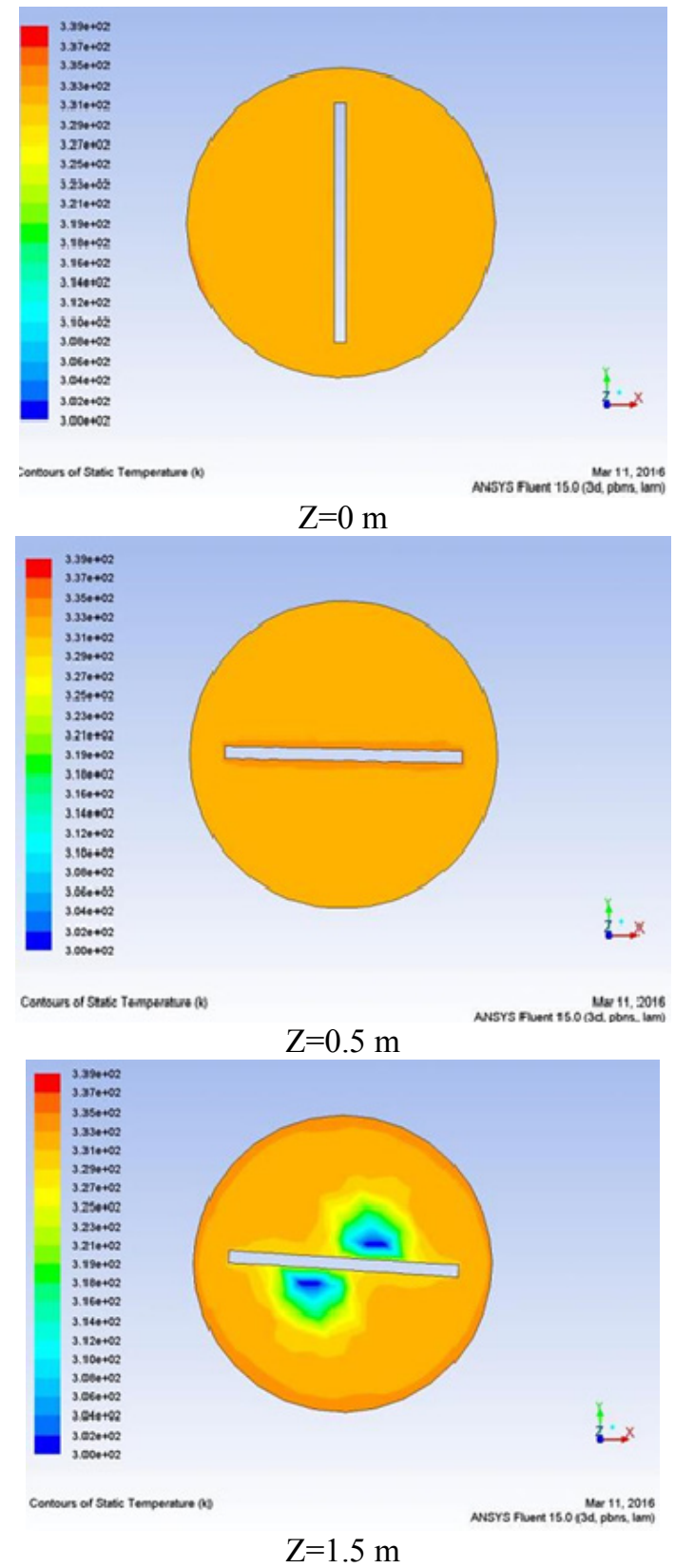

Figure 19. Temperature contours for nanofluid $(\varphi=3 \%)$ and $(\mathrm{Re}=1009)$

Figure (19) shows static temperature contours at locations of $(Z=0,0.5,1.5 \mathrm{~m})$ for volume concentration $(3 \%)$ and $\operatorname{Re}=1009$. These temperature contours show 
an increase in the temperature at the exit with decreasing velocity or nanofluid concentration. This is because the increase in concentration leads to an increase in the number of particles that increases the effective thermal conductivity of the nanofluid, and thereby augments the molecular heat diffusion.

Figure (20) highlights velocity contours at locations $(Z=0,0.5,1.5 \mathrm{~m})$ along the test section for nanofluid of volume concentration $=5 \%$ with $(\mathrm{Re}=2033)$.
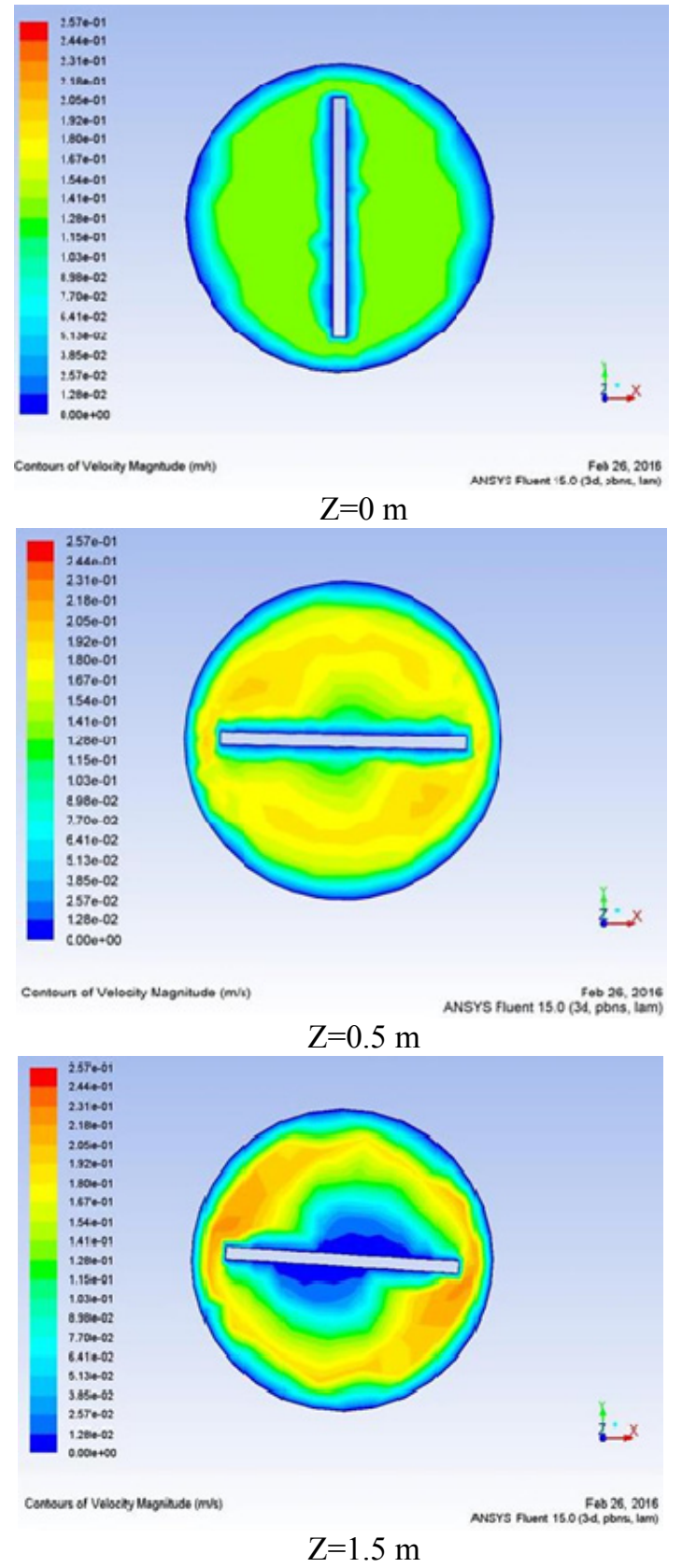

Figure 20. Velocity contours in $(\mathrm{m} / \mathrm{s})$ for nanofluid $(\varphi=5 \%)$ and $(\operatorname{Re}=2033)$

\subsection{Pressure contours}

Figures (21) and (22) illustrate the static pressure drop distribution contours for the circular finned tube with twisted tape insert at two different volumetric flow rates and various axial distances along the test section. From these figures, it can be noted that the pressure drop for nanofluid flowing through the finned tube equipped with twisted tape is higher than the pressure drop for distilled water cases. In addition, the pressure drop increases as the volumetric flow rate increase.
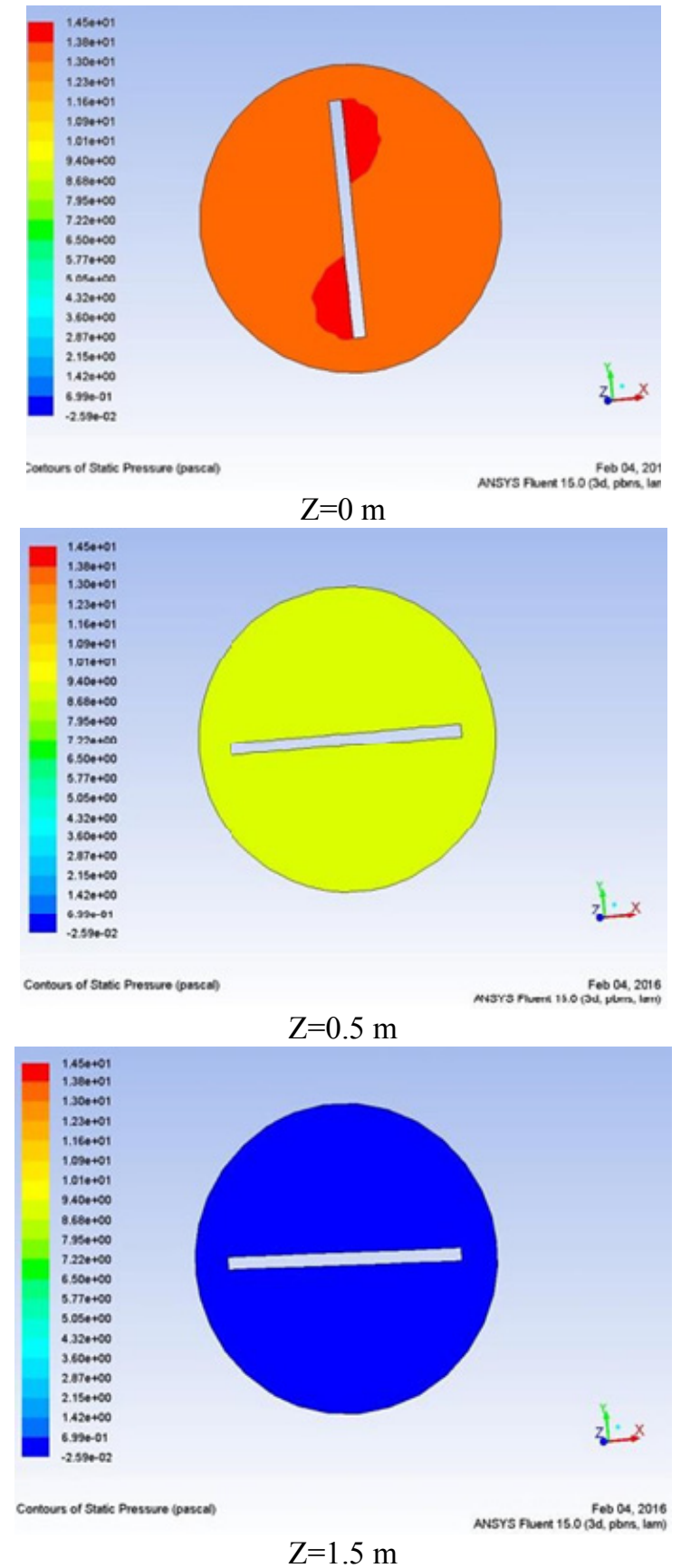

Figure 21. Pressure contours for distilled water at $(\operatorname{Re}=678)$

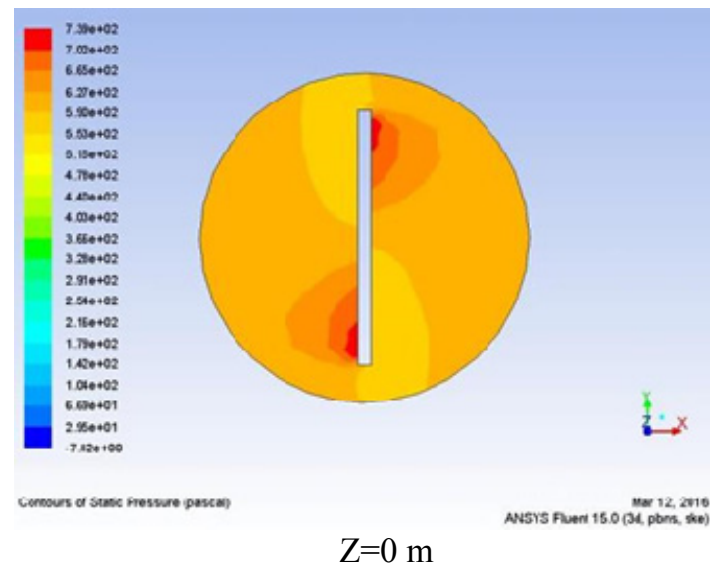



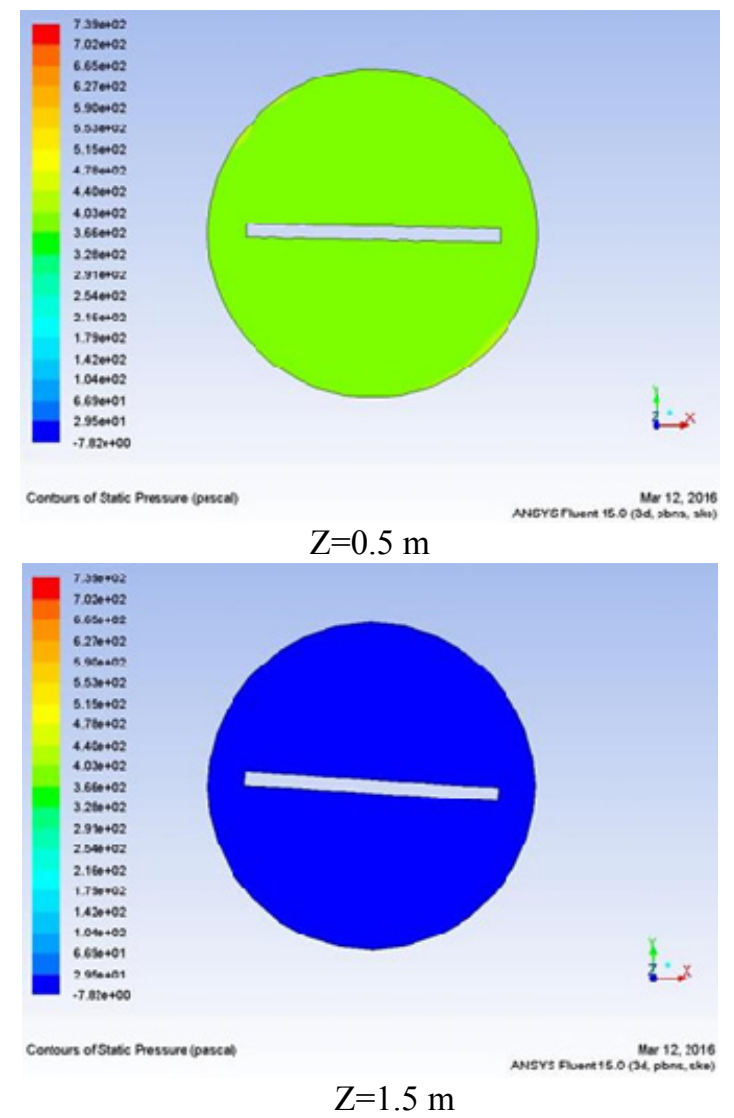

Figure 22. Pressure contours for nanofluid $(\varphi=3 \%)$ and $(\mathrm{Re}=3391)$

\subsection{Thermal performance factor}

In general, it can be recognized that the thermal performance factor above unity indicates that the effect of heat transfer enhancement due to the device modification is more dominant than the effect of rising the friction and vice versa. Figure (23) shows the variation in thermal performance factor with Reynolds number and volume concentration. From this figure, the maximum thermal performance factor for typical twisted tape is (1.4) at Reynolds number (1353), and $(\varphi$ $=5 \%$ ) for laminar flow regime.

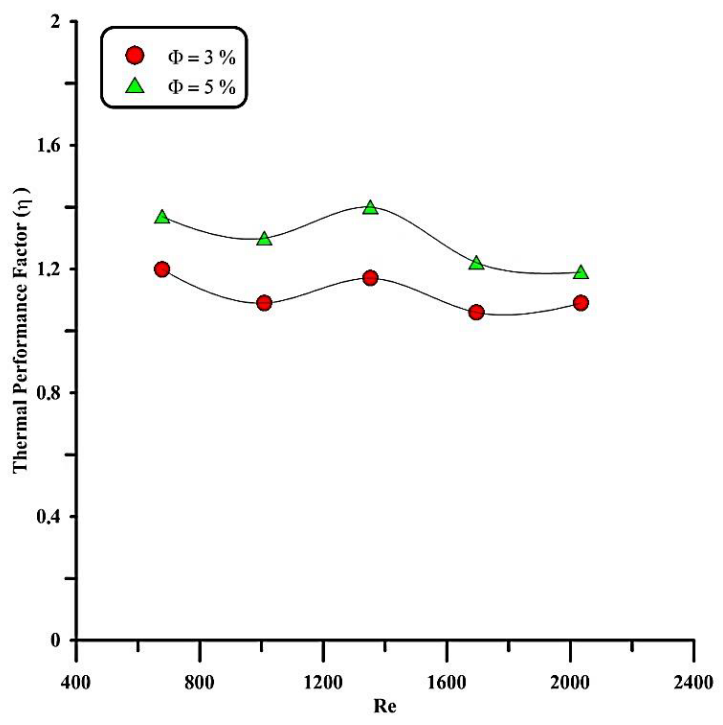

Figure 23. The effect of $(\mathrm{Re})$ and $(\varphi)$ on $(\eta)$ for laminar flow

\section{CONCLUDING REMARKS}

This work presents a numerical investigation of heat transfer performance of finned tube with twisted tape inserted. In addition, the Al2O3/water as nanofluid is employed in the present heat exchanger. The main concluded points of the current study may be summarized as follows:

1- In general, using the nanofluid enhances significantly the heat transfer compared with the base fluid (pure water), with an increase in the pressure drop. The heat transfer enhanced with increasing nanoparticles concentration, and $(\varphi=5 \%)$ gives the higher heat transfer enhancement amongst the studied concentrations.

2- The combined use of the nanofluid and twisted tape provides a higher heat transfer enhancement compared to the individual use of each one.

3- The use of finite volume method with singlephase model in Ansys-Fluent commercial CFD software, generally produces numerical results in good agreement compared with the experimental results. It is found to be relevant for predicting the pipe flow with both nanofluid and twisted tape inside finned tube. Then, for the system analysis, the Static Structural, Transient Structural and coupling system can be used.

4- The temperature of the flow increases and becomes more homogenous with increasing flow rate and concentration.

5- The results of temperature distribution across the pipe along its length show that the temperature is high at the beginning of the pipe and decreases towards the end of the pipe. While, the temperature profile along the pipe decreases with respect to either increasing nanofluid concentration or increasing the velocity.

6- Results of numerical simulations show that adding fins can enhance the heat dissipation through heat exchanger. It is noted that the heat transfer behavior increases within the present model as Reynolds numbers increases.

7- The ratio of $\left(\mathrm{h}_{\mathrm{nf}} / \mathrm{h}_{\mathrm{bf}}\right)$ increases with increasing Reynolds number for both volume concentrations. It is found that the average heat transfer coefficient can be enhanced about $15-40 \%$ with $3 \%$ volume concentration, and increased about $18-46 \%$ with $5 \%$ volume concentration compared to distilled water.

8- The average ratio of $\left(\mathrm{f}_{\mathrm{nf}} / \mathrm{f}_{\mathrm{bf}}\right)$ is about 1.97 for $5 \%$ volume concentration.

\section{REFERENCES}

[1] Choi S. U. S., "Enhancing thermal conductivity of fluid with nanoparticles Developments and Applications of Non-Newtonian flows", D. A. Siginer and H. P. Wangeds., FED, V.231/MD, Vol. 66, 1995, pp. 99-105.

[2] G. Pathipakka, P. Sivashanmugam, "Heat Transfer Behaviour of Nanofluids in a Uniformly Heated Circular Tube Fitted with Helical Inserts in Laminar Flow", Superlatt. Microstruct. 47 (2) (2010) 349-360.

[3] E. Paul, S. Kalyan Yadav, Kumar, "Numerical Simulation and Enhancement of Heat Transfer 
Using CUO/WATER Nanofluid and Twisted Tape with Alternate Axis", International Journal of Mechanical Engineering and Technology (IJMET), Volume 5, Issue 9, September (2014), pp. 323-335.

[4] S. D. Salman, A. A. H. Kadhum, M. S. Takriff, and A. B. Mohamad, "Heat Transfer Enhancement of Laminar Nanofluids Flow in a Circular Tube Fitted with Parabolic-Cut Twisted Tape Inserts", The Scientific World Journal, vol. 2014, Article ID 543231, 7 pages, 2014.

[5] S. D. Salman, A. A. H. Kadhum, M. S. Takriff, and A. B. Mohamad, "Numerical Investigation of Heat transfer and friction factor characteristics in a circular tube fitted with V-cut twisted tape inserts", The Scientific World Journal, vol. 2013, Article ID 492762, 8 pages, 2013.

[6] R. Kharat, N. Bhardwaj, and R. S. Jha, "Development of heat transfer coefficient correlation for concentric helical coil heat exchanger", International Journal of Thermal Sciences, vol. 48, no. 12, pp. 2300-2308, 2009.

[7] J. Balabhaskara Rao, D. Bhanuchandrarao, M. Ashok chakravarthy and K. Srinivasarao, "CFD Simulation of Heanched Heat Transfer in Concentric Tube with Inner Twisted Tape Insert By Using Nano Fluids", International Journal of Engineering Research \& Technology (IJERT), Vol. 2 Issue 11,pp. 2496- 2504, (2013).

[8] Ebenezar Paul, S.Kalyan Yadav and Saravana Kumar," Numerical Simulation and Enhancement of Heat Transfer using $\mathrm{CuO} /$ Water Nanofluid and Twisted Tape with Alternate Axis", International Journal of Mechanical Engineering and Technology (IJMET), Volume 5, Issue 9, September (2014), pp. 323-335.

[9] PaisarnNaphon, "Heat transfer and pressure drop in the horizontal double pipes with and without twisted tape insert", 2005 Elsevier Ltd.

[10] M. Chandrasekar, S. Suresh, A. Chandra Bose, "Experimental studies on heat transfer and friction factor characteristics of $\mathrm{Al} 2 \mathrm{O} 3$ /water nanofluid in a circular pipe under laminar flow with wire coil inserts", Experimental Thermal and Fluid Science 34 (2010) 122-130.

[11] L. S. Sundar, K.V. Sharma, "Turbulent heat transfer and friction factor of $\mathrm{A} 12 \mathrm{O} 3$ nanofluid in circular tube with twisted tape inserts", International Journal of Heat and Mass Transfer 53 (2010) 1409-1416.

[12] J. Guo, A. Fan, X. Zhang, and W. Liu, "A numerical study on heat transfer and friction factor characteristics of laminar flow in a circular tube fitted with center-cleared twisted tape", International Journal of Thermal Sciences, vol. 50, no. 7, pp. 1263-1270, 2011.

[13] Lin Zhi-min, Wang Bi, "Convective Heat Transfer Enhancement in a Circular Tube Using Twisted Tape." J. Heat Transfer, 131, 8, pp. 81-91, 2009.

[14] Yadav Anil, "Effect of Half Length Twisted Tape Turbulator on Heat Transfer \& Pressure Drop Characteristics Inside a Double Pipe U-Bend Heat
Exchanger" Jordan journal of Mech. \& Industrial Eng. 3, 1, pp.17-22, 2009.

[15] Sudarmadji Sudarmadji, Sudjito Soeparman, Slamet Wahyudi, Nurkholis Hamidy, "Effects of Cooling Process of $\mathrm{Al} 2 \mathrm{O} 3$ water Nanofluid on Convective Heat Transfer", Faculty of Mechanical Engineering, Belgrade, FME Transactions (2014) 42, 155-161.

[16] Sudarmadji Sudarmadji, "A New Correlation for Pressure Drop in The Cooling Process of AL2O3Water Nanofluid in Pipes", Faculty of Mechanical Engineering, Belgrade, FME Transactions (2015) 43, 40-46.

[17] Madhu. B., Bala Subramanian. E., Nagarajan. P.K., Ravishankar Sathyamurthy, Mageshbabu. D., "Improving the Yield of Freshwater and Exergy Analysis of Conventional Solar Still with Different Nanofluids", Faculty of Mechanical Engineering, Belgrade, FME Transactions (2017) 45, 524-530.

[18] Wang, X., Xu, X. and Choi, S.U.S. 1999. "Thermal conductivity of Nanoparticle-fluid mixture", Joural of Thermo physics and Heat Transfer. 13 (4), 474-480.

[19]Buongiorno, J., "Convective Transport in Nanofluids", Journal of Heat Transfer, pp.128-240, 2006.

[20]Laith J. Habeeb, Fouad A. Saleh, Bassim M. Maajel, "Experimental Investigation of Laminar Convective Heat Transfer and Pressure Drop of A12O3/Water Nanofluid in Circular Tube Fitted with Twisted Tape Insert", International Journal of Energy Applications and Technologies, Vol. 4, Issue 2, pp. 73-86, 2017.

\section{NOMENCLATURE}

$C_{p} \quad$ Specific heat $\left(\mathrm{kJ} \cdot \mathrm{kg}^{-1},{ }^{\circ} \mathrm{C}^{-1}\right)$

$D \quad$ Tube diameter $(\mathrm{m})$

$f \quad$ Friction factor (dimensionless)

$k \quad$ Thermal conductivity $\left(\mathrm{W} \cdot \mathrm{m}^{-1},{ }^{\circ} \mathrm{C}^{-1}\right)$

$L \quad$ Tube length (m)

$m \quad$ Mass flow rate $\left(\mathrm{kg} \cdot \mathrm{s}^{-1}\right)$

$R e \quad$ Reynold's number (dimensionless)

$T$ Temperature $\left({ }^{\circ} \mathrm{C}\right)$

$T T$ Twisted tape (dimensionless)

TR Twist ratio (dimensionless)

$V \quad$ Main velocity $\left(\mathrm{m} \cdot \mathrm{s}^{-1}\right)$

$w \quad$ Tape width (mm)

$x, y, z \quad$ Coordinates

\section{Greek Symbols}

$\begin{array}{ll}\Delta P & \text { Pressure drop }(\mathrm{Pa}) \\ \rho & \text { Density }\left(\mathrm{kg} \cdot \mathrm{m}^{-3}\right) \\ \eta & \text { Thermal performance factor (dimensionless) } \\ \varphi & \begin{array}{l}\text { Nanoparticle volume concentration } \\ \text { (dimensionless) }\end{array}\end{array}$

\section{Subscripts}

$\begin{array}{ll}p & \text { Particles } \\ n f & \text { Nanofluid } \\ b f & \text { Base fluid }\end{array}$




\section{СЕD МОДЕЛИРАњЕ ЛАМИНАРНОГ \\ СТРУЈАњА И ПРЕНОС ТОПЛОТЕ КОРИШЋЕЊЕМ НАНОФЛУИДА БАЗИРАНОГ \\ НА ВОДИ И AL2O3 У ФИН ЦЕВИ СА УКРИВЉЕНОМ ТРАКОМ}

\section{Л.Ј. Хабеб, Ф.А. Салех, Б.М. Мајел}

Рад приказује нумеричко истраживање повећања преноса топлоте применом нанофлуида састављеног од воде и $\mathrm{A} 12 \mathrm{O} 3$ који се креће кроз цев кружног попречног пресека у условима константне улазне температуре и режима ламинарног струјања. Истраживање је вршено при различитом запреминском уделу нанофлуида ( $3 \%$ и $5 \%)$, односу укривљене траке и укривљености $(1,85)$ и вредности Рејнолдсовог броја од 678 - 2033 при ламинарном струјању. Нумеричка анализа је коришћена за решавање основних парцијалних диференцијалних једначина код три димензије. Приказани су резултати добијени за структуру струјања, вектор брзине и температурско поље. Нумерички резултати показују да је брзина преноса топлоте израженија при коришћењу нанофлуида. Максимално побољ-шање од $46 \%$ се добија код коефицијента преноса топлоте конвекцијом коришћењем нанофлуида са запреминским уделом од 5\% и Рејнолдсовим бројем чија је вредност 678 у поређењу са чистом водом. Такође је утврђено да се пренос топлоте побољшава са повећањем концентрације запремине честица и Рејнолдсовим бројем. 